\title{
PERSPECTIVE OPEN \\ Exploring the current state of play for cost-effective water treatment by membranes
}

\author{
Nidal Hilal ${ }^{1}$ and Chris J. Wright ${ }^{2}$
}

This article presents a perspective on the current development and application of membranes for the treatment of water. We examine how membranes contribute to the global challenge of sustainable supply of clean water. The main theme is on desalination and how innovative science and emerging technology is being applied. Thus, we appraise how techniques such as advanced membrane materials, biomimetic membranes, hybrid systems, forward osmosis, and membrane distillation are being used to improve production to meet the increasing global demand for water.

npj Clean Water (2018)1:8; doi:10.1038/s41545-018-0008-8

\section{INTRODUCTION}

The energy-efficient sustainable treatment of water is one of the key issues of the twenty-first century and with current global population growth this importance is only going to increase. According to the United Nations there are over 748 million people that do not have access to an improved source of drinking water, and water demand from industry is expected to increase by 400 percent between 2000 and 2050 globally. ${ }^{1}$ In addition, more than 3.4 million people die each year from water hygiene-related causes. ${ }^{2}$ This is a dire problem for developing countries with poor infrastructure and limited financial leverage. However, this is a global issue as estimates have predicted that half of the world's population will suffer severe water shortages by $2050 .^{2}$ This will be compounded by the world's population growth, set to increase from 7.6 billion at present to 9.8 billion by $2050 .^{3}$ This indicates that the requirement for fresh water and management of waste water will dramatically increase. There is not enough natural fresh water to meet this vast demand. Thus, complacency is not an option for global water management if water shortages and conflict over water are to be avoided. The water processing industry must develop new treatment methods and increase water resources as a matter of urgency. Membrane-based processes and desalination have emerged as technologies that will answer these challenges. This promise is recognized in market predictions with the global desalination market, according to report by SBI Energy, set to reach US\$52.4 billion in 2020, an increase of $320 \%$ from US $\$ 12.5$ billion in $2010 .{ }^{4}$ Reverse osmosis is set to have the largest growth in the membrane market segment reaching US\$40 billion by $2020 .{ }^{4}$

Desalination is dramatically increasing the amount of water resources that are available for the production of potable water and membrane desalination and thermal processes are the most common methods. Thermal processes require a large amount of energy to achieve evaporation and condensation of water, through techniques such as vapor compression, humidification dehumidification, and multi-stage flash. ${ }^{5}$ Energy is the biggest cost in desalination, accounting for up to half of the total cost of fresh water production. ${ }^{6}$ Indeed, the resources of energy and water are intimately related with $7 \%$ of all energy consumed globally used to produce fresh water. ${ }^{7}$ In recent years, the energy needed for desalination has decreased significantly. ${ }^{8}$ This is due to the development of more efficient pumps, energy recovery devices, process configuration, and membranes. In comparison to thermal processes, membrane desalination technologies have the advantage of comparatively low energy ${ }^{5}$ requirements and they are based on processes such as reverse osmosis (RO), forward osmosis (FO), electrodialysis (ED), and nanofiltration (NF) that desalinate water by rejecting salt at a membrane barrier. The application of membranes is growing and we believe that it is still in its infancy. This article will examine the current status of membrane science and engineering as it endeavors to create efficient membrane processes that will provide cost-effective water treatment for the global population.

\section{Challenges facing membranes}

There are many different forms of membrane separation processes all with the same underlying principle of a selective barrier allowing the differential passage of material, depending on the relationship between the physical and chemical properties of the solute(s), solvent, and the membrane. A pressure difference across the membrane is the driving force for the separation process with the solvent passing through the membrane and the different solutes being either retained or passing through the membrane. The passage of the solutes across the membrane is governed by a convolution of their size, charge, activity, and partial pressure. Membranes and membrane processes are defined by the materials they separate or the applied driving force and all membranes microfiltration (MF), ultrafiltration (UF) $\mathrm{NF}$, and RO have been used in the treatment of water. The material of the membrane governs the efficiency of the separation process and is arguably the focus of a lot of research ${ }^{9,10}$ that has shown greatest promise to overcome some of the problems,

\footnotetext{
${ }^{1}$ Centre for Water Advanced Technologies and Environmental Research (CWATER), College of Engineering, Swansea University, Fabian Way, Swansea SA1 8EN, UK and

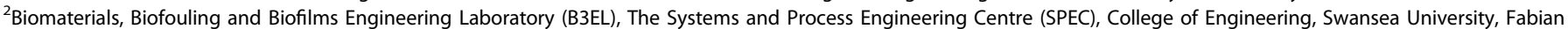
Way, Swansea SA1 8EN, UK

Correspondence: Nidal Hilal (N.Hilal@swansea.ac.uk)
}

Received: 16 August 2017 Revised: 6 December 2017 Accepted: 11 December 2017

Published online: 07 June 2018 
principally fouling and salt-scaling, that have limited the application of membrane processes in water treatment.

The efficiency of a membrane process is compromised by fouling of the membrane surfaces, which in many cases is inevitable for the materials being processed, and places economic constraints on the adoption of membrane technology for some water treatments. ${ }^{11}$ The fouling can be reversible or irreversible and the extent is governed by the surface properties of the membrane and its interactions with the feed components. The deposition of a foulant layer during normal process operation results in changes in the chemical and physical properties of the membrane that must be addressed by regular cleaning regimes that restore the membrane efficiency. This will have economic impact for the water treatment plant. ${ }^{8}$ If foulant layers are allowed to build up, the surface that interacts with the feed stream will be modified with changes in surface roughness, hydrophobicity, charge, and decreasing pore size. ${ }^{11}$ Of particular concern is biofouling, which is a serious problem for RO desalination plants. ${ }^{12}$ Many conventional pre-treatment processes fail to protect the desalination plant from biological materials in the feed water that act as nutrients for microorganism at the membrane module surfaces. This results in biofilms that compromise the function of the membrane and are hard to remove. ${ }^{13}$ There exists a real need for improved pre-treatment strategies and membranes with reduced adhesion for biological materials, and improved chemical and mechanical robustness for membrane tolerance of cleaning strategies.

Scaling is another problem that often affects RO desalination plants and occurs when the salt concentration becomes saturated and forms crystals on the membrane surfaces. ${ }^{12}$ Scales that are often deposited on RO membranes include calcium sulfate, calcium carbonate, barium sulfate, and silicates. Industry has developed three techniques that have been applied to mitigate scaling problems. These are addition of antiscalant, alteration of feed water properties and optimization of process design. ${ }^{12}$ The most popular preventative method for scale formation is the addition of an antiscalant due to limitations of the other methods. Acidification is used to adjust the $\mathrm{pH}$ of feed waters in order to change the solubility of scale, but with care not to promote the formation of sulfate scales. ${ }^{14}$ To optimize operating parameters, scaling is reduced by lowering product recovery, however this has economic impacts as the efficiency of the plant is reduced. ${ }^{12}$

Fluctuations in the feed from pre-treatment to a desalination unit, monitored in terms of silt density index (SDI), also impact on the efficiency of the process with the need for frequent backwashing, higher rates of chemical consumption for coagulant and $\mathrm{pH}$ adjustment, and blocked media filters faced. ${ }^{12}$ Conventional pre-treatment processes can be susceptible to changes in the quality of the raw seawater with seasonal variations due to climatic conditions such as dust storms and wind. The failure to treat feed waters with extreme SDI causes severe deterioration of RO membranes. In order to better manage fluctuation in feed quality in terms of $\mathrm{pH}$, temperature, alkalinity, natural organic matter, and turbidity, the pre-treatment of desalination plants can be modified with changes in the $\mathrm{pH}$ adjustment and coagulant dosing rates alongside fine tuning of backwashing procedures. ${ }^{14}$ However, these reactive procedures are difficult to control and allow slight improvements in the efficiency of water treatment. More must be done in terms of process design and membrane material development in order to widen the tolerances of membrane processes challenged with waters of different qualities.

\section{Advanced membrane technologies}

Looking to the future, there are key areas where technology is emerging that will reduce the limitations of membranes and significantly impact on the efficiency of water treatment and potable water production. In the authors' opinion, these areas include advanced membrane materials, forward osmosis, biomimetic membranes, membrane distillation, and hybrid membrane systems. Integrated or hybrid membrane systems are an interesting option for membrane technologists and have been demonstrated to improve water treatment and desalination compared to conventional systems. ${ }^{15-17}$ A hybrid membrane system as it's name suggests is a process that brings together a membrane filtration unit with other processes such as coagulation, ionexchange adsorption, or another membrane system. The efficiency and choice of component processes depend mainly on the qualities of the feed water and the product water. Thus, each water treatment/RO desalination plant potentially requires a different combination of hybrid and pre-treatment processes. For example, a seawater of poor quality requires extensive pretreatment upstream to the RO membrane, while a good grade of groundwater requires only simple coagulation prior to an NF membrane system to produce potable water. ${ }^{12}$

Forward osmosis has been a controversial technology that when it first emerged gained a lot of researcher's attention because of its energy efficiency promise. However, the technical challenges of the technology have meant that this promise has been subdued, and more realistic goals have been ascribed. What is not in dispute is that FO presents an advantage over RO in that it does not require a hydraulic pressure as driving force; $\mathrm{FO}$ has a concentrated solution that creates an osmotic pressure gradient across a semipermeable membrane that draws fresh water from the feed solution. ${ }^{18,19}$ Thus, FO has joined the tool box for membrane treatment of water and for some feeds for desalination this will be of benefit. However, with the caveat that FO does require energy, thus to reap the benefits the process must be coupled to an economic energy source, such as the discharged heat of a power plant.

Membrane distillation (MD) promises to provide attractive features for the desalting of highly saline waters. ${ }^{20}$ However, optimization of MD is still dominated by laboratory studies and industrial scale research is limited. This needs to be addressed for the advantages of $M D$ to be realized. $M D$ is a thermally driven separation based on an MF membrane process, in which only vapor molecules pass through a hydrophobic membrane with a driving force created by a vapor pressure difference between the membrane surfaces. In comparison to conventional processes, MD has lower hydrostatic pressures and operating temperatures (the water is not necessarily heated to boiling point). ${ }^{20}$ In addition, the cost of materials is reduced as plastics can be used, thus alleviating corrosion problems.

Biological cells arguably possess the best apparatus for separation processes, and thus are a source of inspiration and molecular devices for water treatment. Indeed, recent developments in desalination research have produced bio-inspired membranes with very high water permeability, salt rejection, and stability. ${ }^{21}$ Most success in bio-inspired membranes has exploited aquaporins that are transport proteins located in living cell membranes. Aquaporins are selective channels, which can reject virtually everything apart from water, and are capable of transporting up to one billion water molecules per second with a permeability that is 5-1000 times greater than those of conventional membranes. ${ }^{21}$ The use of proteins to fabricate synthetic membranes raises issues related to stability of the protein structure and its functionality; any disruption of the protein structure during membrane fabrication and/or operation will compromises the aquaporins activity. Aquaporin-based membranes fabricated via interfacial polymerization have recently shown stable performance over months and have been commercialized. ${ }^{22}$ However, major technical challenges remain that need to be addressed including stability of aquaporins during extraction, membrane fabrication, and operation in high salinities, such as seawater, and the development of cleaning chemicals that can 
be tolerated by the labile biomimetic membrane to allow the removal of fouling and scaling. ${ }^{21}$

Membranes can be fabricated and/or modified using a large number of materials that install the advantages of control over selectivity and the potential to tailor membrane performance. Thus, a lot of research has focussed on the area of advanced membrane materials (AMM) to enhance resistance to extremes in process conditions and improve resolution of mixtures. ${ }^{9,10}$ This strategy is highly successful as there is no need for the development and optimization of process equipment; the materials of membranes already operating at scale can be modified. In many cases the development of AMMs has looked to polymer blending and nanocomposite polymers to change the chemical and mechanical functionality of the membrane surface. A major initiative for AMM research has been on graphene, which has triggered much excitement and promise. ${ }^{23,24}$ Graphene consists of a two-dimensional monoatomic-thick building blocks of a carbon allotrope. Compared to carbon nanotubes and carbon fiber, it has a higher aspect ratio and surface area. This infers better mechanical, thermal, and electrical properties on graphene, which can be exploited for fabrication of materials for water treatment in terms of both absorbents and membranes with improved functionality and efficiency. ${ }^{23}$ Another advantage is that graphene oxide and reduced graphene oxide are easily synthesized through chemical exfoliation of graphite, without the need for metallic catalysts or sophisticated apparatus and any further purification steps. In recent laboratory studies, graphene and its derivatives have been used in both $\mathrm{RO}$ and FO desalination. ${ }^{25}$ Single-layer porous graphene can be used as a desalination membrane with pores of controllable size, with impressive water fluxes and nearly $100 \%$ salt rejection rates, when operated under hydraulic or osmotic pressure. The properties of graphene can also be imparted to polymeric membranes by fabrication of nanocomposite membranes. Such membranes have demonstrated high hydrophilicity and anti-fouling properties against proteins and bacterial cells. ${ }^{24}$ Graphene and its derivatives have also enhanced the mechanical performance of membranes during operation and cleaning, achieved by very low filler amounts in the polymer matrix of the membrane.

\section{CONCLUSION}

To conclude this article, we believe that membrane-based technologies are essential for the future of water treatment. There are a number of advanced technologies that we believe are key for the sustainable production of fresh water and these include forward osmosis, hybrid systems, and membrane distillation. However, it is research on advanced membrane materials which currently provide the most promise as this aims to improve the functionality of membranes already operating at economically viable scales. We hope the reader is inspired to investigate further the technologies we have identified that exhibit the potential to meet the challenges and opportunities now faced by the global community in terms of sustainable and cost-efficient water production.

\section{AUTHOR CONTRIBUTIONS}

N.H. and C.J.W. contributed equally to the discussion, literature review, and writing of this article.

\section{ADDITIONAL INFORMATION}

Competing interests: The authors declare no competing interests.
Publisher's note: Springer Nature remains neutral with regard to jurisdictional claims in published maps and institutional affiliations.

\section{REFERENCES}

1. WWAP (United Nations World Water Assessment Programme). The United Nations World Water Development Report 2015: Water for a Sustainable World (UNESCO, Paris, 2015).

2. Prüss-Üstün, A., Bos, R., Gore, F. \& Bartram, J. Safer Water, Better Health: Costs, Benefits and Sustainability of Interventions to Protect and Promote Health (World Health Organization, Geneva, 2008).

3. United Nations. World Population Prospects: The 2017 Revision, Key Findings and Advance Tables. Working paper no. ESA/P/WP/248 (Department of Economic and Social Affairs, Population Division, United Nations, New York, 2017).

4. Working with Water. Desalination market to reach US\$52.4bn by 2020 . Working with Water 29 August 2011 http://workingwithwater.filtsep.com/. Accessed 14 August 2017.

5. Kesieme, U. K., Milne, N., Aral, H., Cheng, C. Y. \& Duke, M. Economic analysis of desalination technologies in the context of carbon pricing, and opportunities for membrane distillation. Desalination 323, 66-74 (2013).

6. Zhou, Y. \& Tol, R. S. J. Evaluating the costs of desalination and water transport. Water Resour. Res. 41, 1-10 (2005).

7. Mahmoudi, $\mathrm{H}$. et al. Renewable Energy Technologies for Desalination (CRC Press, Boca Raton, 2017).

8. Ghaffour, N., Missimer, T. M. \& Amy, G. L. Technical review and evaluation of the economics of water desalination: Current and future challenges for better water supply sustainability. Desalination 309, 197-207 (2013).

9. Hilal, N., Ismail, A. \& Wright, C. J. Membrane Fabrication (CRC Press, Boca Raton, 2015).

10. Hilal, N., Khayet, M., \& Wright, C. J. Membrane Modification: Technology and Applications (CRC Press, Boca Raton, 2012).

11. Hilal, N., Ogunbiyi, O. O., Miles, N. J. \& Nigmatullin, R. Methods employed for control of fouling in MF and UFmembranes: a comprehensive review. Sep. Sci. Technol. 40, 1957-2005 (2005).

12. Ang, W., Mohammad, A., Benamor, A., Hilal, N. \& Leo, C. Hybrid coagulation-NF membrane process for brackish water treatment: effect of antiscalant on water characteristics and membrane fouling. Desalination 393, 144-150 (2016).

13. Powell, L., Hilal, N. \& Wright, C. J. Atomic force microscopy study of the biofouling and mechanical properties of virgin and industrially fouled reverse osmosis membranes. Desalination 404, 313-321 (2017).

14. Antony, A. et al. Scale formation and control in high pressure membrane water treatment systems: a review. J. Membr. Sci. 383, 1-16 (2011).

15. Hilal, N., Kochkodan, V., Al Abdulgader, H., Mandale, S. \& Al-Jlil, S. A combined ion exchange-nanofiltration process for water desalination: I. sulphate-chloride ionexchange in saline solutions. Desalination 363, 44-50 (2015).

16. Hilal, N., Kochkodan, V., Al Abdulgader, H. \& Johnson, D. A combined ion exchange-nanofiltration process for water desalination: II. Membr. Sel. Desalin. 363, 51-57 (2015).

17. Hilal, N., Kochkodan, V., Al Abdulgader, H., Mandale, S. \& Al-Jlil, S. A combined ion exchange-nanofiltration process for water desalination: III. Pilot Scale Stud. Desalin. 363, 58-63 (2015).

18. Chung, T., Zhang, S., Wang, K. Y., Su, J. \& Ling, M. M. Forward osmosis processes: yesterday, today and tomorrow. Desalination 287, 78-81 (2012).

19. Shaffer, D. L., Werber, J. R., Jaramillo, H., Lin, S. \& Elimelech, M. Forward osmosis: where are we now? Desalination 356, 271-284 (2015).

20. Alkhudhiri, A., Darwish, N. \& Hilal, N. Membrane distillation: a comprehensive review. Desalination 287, 2-18 (2012).

21. Giwa, A. et al. Biomimetic membranes: a critical review of recent progress. Desalination. https://doi.org/10.1016/j.desal.2017.06.025 (2018).

22. Tang, C. Y., Zhao, Y., Wang, R., Hélix-Nielsen, C. \& Fane, A. G. Desalination by biomimetic aquaporin membranes: review of status and prospects. Desalination 308, 34-40 (2013).

23. Santhosh, C. et al. Role of nanomaterials in water treatment applications: a review. Chem. Eng. J. 306, 1116-1137 (2016).

24. Al Aani, S., Wright, C. J., Atieh, M. \& Hilal, N. Engineering nanocomposite membranes: addressing current challenges and future opportunities. Desalination 401, 1-15 (2017).

25. Surwade, S. P. et al. Water desalination using nanoporous single-layer graphene. Nat. Nanotechnol. 10, 459-464 (2015). 
Open Access This article is licensed under a Creative Commons Attribution 4.0 International License, which permits use, sharing, adaptation, distribution and reproduction in any medium or format, as long as you give appropriate credit to the original author(s) and the source, provide a link to the Creative Commons license, and indicate if changes were made. The images or other third party material in this article are included in the article's Creative Commons license, unless indicated otherwise in a credit line to the material. If material is not included in the article's Creative Commons license and your intended use is not permitted by statutory regulation or exceeds the permitted use, you will need to obtain permission directly from the copyright holder. To view a copy of this license, visit http://creativecommons. org/licenses/by/4.0/.

(c) The Author(s) 2018 